\title{
Induction of fertile cycles in the Blackhead sheep during the anoestrus period
}

\section{Summary}

A continuous supply of lambs is expected from the market, but not realizable without additional administration of hormones in seasonal breeds kept under extensive conditions. Our study had the aim to work out a possibility to induce fertile cycles in a flock of the Blackhead sheep already in early summer. Analyses of hormones progesterone and $\mathrm{LH}$ in untreated ewes were used, together with other tools, to control the different treatments for success, e.g. induction of ovulation, appearance of oestrus signs, regular luteal phases or pregnancy. Annual treatments were performed on altogether 76 ewes and started in June (1998), May (1999-2001), or April (2002). All tested variants had the main aim to overcome the GnRH/LH deficiency in the summer period. First series of experiments with either a single GnRH injection, a pheromone-containing paste or FSH showed unsatisfying results. An improvement was found after a previous progesterone priming which may have simulated a luteal phase of the oestrous cycle. Further modifications of the second part of treatment revealed a successful stimulation after as well a sequential GnRH agonist administration as a PMSG regime detected by plasma progesterone and ultrasonographic analyses. Finally, births of a single lamb and a pair of twins, respectively, already in October demonstrated the essential potency of both treatment regimes. However, a simplification, i.e. reducing the number of injections, and an optimisation of added hormone amounts are necessary. At the same time, changed conditions for keeping both the pregnant ewes and earlier born lambs have to be considered.

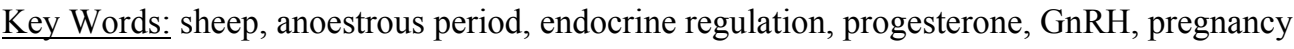

\section{Zusammenfassung}

Titel der Arbeit: Auslösung fertiler Zyklen beim Schwarzköpfigen Fleischschaf im Anöstrus

Vom Markt wird eine kontinuierliche Bereitstellung von Schlachtlämmern gewünscht. Dieses Ziel ist bei extensiv gehaltenen Rassen mit saisonalem Anöstrus nur durch zusätzliche Verabreichung von Hormonen zu erreichen. Wir untersuchten in einer Herde des Schwarzköpfigen Fleischschafes, die unter dem Gesichtspunkt „Landschaftspflege“ gehalten wurde, ob eine Hormonsubstitution in der Lage ist, bereits im frühen Sommer fertile Zyklen auszulösen $(n=76)$. Zu ausgewählten Zeitpunkten wurden Blutplasmakonzentrationen der Hormone Progesteron und LH bestimmt, um, zusammen mit weiteren Methoden, den Erfolg der Behandlungen, z.B. Auftreten von Östren, Auslösung von Ovulationen, von regulären Lutealphasen oder Vorliegen von Trächtigkeiten, zu kontrollieren. Die Behandlungen wurden einmal jährlich vorgenommen und im Juni (1998), Mai (1999-2001) oder April (2002) gestartet. Alle Varianten hatten das Ziel, den GnRH/LH-Mangel in der Sommerperiode auszugleichen. Die ersten Experimente mit einer einzelnen GnRH-Injektion, einer pheromonhaltigen Paste oder mit FSH blieben erfolglos. Eine Verbesserung wurde durch ein vorheriges Priming mit Progesteron zur Simulation einer Lutealphase erreicht. Von verschiedenen Modifikationen der Folgebehandlung waren sowohl durch eine sequentielle GnRH-Agonist - Administration als auch ein PMSG-Regime erfolgreiche Stimulationen möglich. Schließlich zeigten die bereits im Oktober erfolgten Geburten von einem Lamm bzw. einem Pärchen die grundsätzliche Eignung beider Kombinationen. Eine Vereinfachung der Behandlung, z.B. durch Reduzierung der Zahl der Injektionen und der Optimierung der zugeführten Hormonmengen, ist mit Sicherheit möglich. Parallel dazu sind in der zuchthygienischen Arbeit die veränderten Bedingungen für die Haltung sowohl der tragenden Muttern als auch der frühergeborenen Lämmer zu berücksichtigen. 


\section{Introduction}

During last years the main interest in sheep keeping raised the production of meat instead that of wool together with the increasing importance of sheep for the cultivation of landscape (PETERS, 2000; ZUPP and REHBOCK, 2000). At presence, the German sheep production enclosing nearly 2.8 millions of animals provides approximately $45 \%$ of the German market (ZUPP, 2002). A growing interest arises to produce more and continuously lambs for the market. Such efforts are, however, limited for the pure-bred Blackhead and other meat breeds with a seasonal fertility whose percentage contributes actually approximately $90 \%$ of the total stock. Begin and duration of season are breed, location and nutrition dependent and, moreover, affected by social signals from flockmates. Sheep and other domesticated species respond to the annual cycle in daylength to time the seasonal changes in food intake, fattening, gonadal activity, lactation and many other characteristics. Photoperiodic information is translated into a daily cycle of melatonin secretion (LINCOLN, 1992; ARENDT, 1998). Melatonin levels which are high at night and low during the day affect the pulsatile secretion of GnRH from the hypothalamus (MALPAUX et al., 1999) and, consequently, the LH release from the pituitary and presence or absence of ovulation. A complex management, the treatment by melatonin to simulate an autumn/winter-period and the stimulating effect of ram presence, was not successful to produce cyclic ewes in July or earlier, the time of year that is required to produce lambs for spring markets (O'CALLAGHAN, 1999). It was, therefore, the aim of this study in a flock of Blackhead ewes extensively kept for conservation of landscape evaluate other approaches to shorten the period between two breeding seasons. In cyclic ewes, the onset of the LH surge during the follicular phase is coincident with the initiation of a massive and sustained increase in $\mathrm{GnRH}$ secretion which continues well beyond the surge of $\mathrm{LH}$ and its amplitude may exceed that needed to generate the $\mathrm{LH}$ surge (BOWEN et al., 1998). The importance of prolonged GnRH secretion is seen in the maintenance of receptive behaviour, prolonging the initial triggering effect of estradiol (CARATY et al., 2002). It is known, that ovulation is blocked, when progesterone concentrations are elevated. However, progesterone priming seems to be essential for the full expression of the positive feedback effect of estradiol in inducing the preovulatory GnRH surge (CARATY and SKINNER, 1999). There is no seasonal difference in time course or amplitude of the LH surge as demonstrated in ovarectomized ewes which were held in an artificial luteal phase (MOENTER et al., 1990). The pituitary of acyclic ewes is fully equipped with GnRH receptor mRNA to respond to $\mathrm{GnRH}$, but $\mathrm{LH}$ secretion and the rapid, transient increase in intracellular $\left[\mathrm{Ca}^{2+}\right]$ are uncoupled. The only limiting factor for $\mathrm{LH}$ secretion is, therefore, infrequent GnRH stimulation (GHOSH et al., 1996) compared with the situation in cyclic ewes (KARSCH et al., 1997). The hormonal imbalance results in failure of final follicular growth and ovulation in the non-breeding season. However, the total number of antral or ovulatory-sized follicles is comparable, and the largest follicles exhibit a wave-like growth pattern (SOUZA et al., 1996; REHBOCK et al., 1999; ABDENNEBI et al., 2002; GIUCCI and KAULFUSS, 2002). We have proofed the effectiveness of modified regimes of hormonal treatment which were used by others, e.g. BASIOUNI et al. (1996), KHALID et al. (1997), UNGERFELD and RUBIANES (1999), under our specific prerequisites. Our experiments in a flock of Blackheads were started after weaning in May of years 1998-2002 by administration of single 
hormones followed later by combinations. The data of a previous three-years-study on the development of the plasma progesterone $\left(\mathrm{P}_{4}\right)$ concentration during anoestrus (REHBOCK et al., 1999) served as a basis for the evaluation of treatments. Effects of single or multiple injections of either a GnRH agonist, $\mathrm{PMSG}$ or $\mathrm{FSH}$, given after a $\mathrm{P}_{4}$ pretreatment were again recorded by the $\mathrm{P}_{4}$ level, LH and FSH concentrations, oestrus signs, and ultrasonography.

\section{Material and Methods \\ Animals and hormonal treatments}

Annual experiments (Exp. I-V) were performed, beginning in 1997 and finished in 2002 (Table 1). During each year, Blackhead Mutton ewes (total $n=76$ ) were randomly selected after lambing and weaning from the flock and kept either separately for the period of hormonal treatment and blood sampling, but mostly together with the flockmates on the pasture. Our efforts were directed on detection of significant changes in hormone levels detectable by a small number of samples. Bleeding was, therefore, restrained to preserve extensive conditions of keeping without needs for catheterisation. Ewes of Exp. III-V were held together with a fertile ram. The volume of blood samples taken from the vena jugularis by punctuation during short-time fixation was $6-10 \mathrm{ml}$ which was drawn in commercial sampling tubes containing EDTA-K as anticoagulans (KABE, Nuembrecht, Germany) and centrifuged within $2 \mathrm{~h}$ to separate plasma. Plasma aliquots were frozen at $-20^{\circ} \mathrm{C}$ and held there until analysis of hormonal parameter. Following hormonal preparations were used in Exp. II-V (Table 1): GnRH agonist (Gonavet ${ }^{\circledR}$; Veyx, Germany), a paste containing pheromone (friendly given by KAULFUSS), FSH (Ovagen ${ }^{\mathrm{TM}}$, The Netherlands), PMSG (eCG; Pregmagon ${ }^{\circledR}$; IDT, Germany), and $\mathrm{P}_{4}\left(\mathrm{P}_{4}\right.$ valerate; Eifelfango, Germany), $\mathrm{PGF}_{2 a l p h a}$ (Essex, Germany).

Table 1

Hormonal manipulations of anoestrous Blackhead Mutton sheep $(n=76)$ kept under extensive conditions throughout years 1997-2002 (Hormonelle Behandlungen anoestrischer SKF-Schafe $(\mathrm{n}=76)$ unter Feldbedingungen während der Jahre 1997-2002)

\begin{tabular}{|c|c|c|c|c|c|}
\hline$\overline{\text { Exp. }}$ & Year & $\begin{array}{l}\text { Begin of } \\
\text { treatment }\end{array}$ & $\mathrm{n}$ & Main elements of treatment & $\begin{array}{c}\text { Data of } 1^{\text {st }} \text { lambing after } \\
\text { treatment }\end{array}$ \\
\hline I & 1997 & March & 6 & no treatment (control) & January - March 1998 \\
\hline II & 1998 & June 24 & 16 & $\begin{array}{l}50 \mu \mathrm{g} \text { GnRH agonist (GnRH) or } \\
5 \mathrm{~mL} \text { of a Pheromone-containing paste }\end{array}$ & January - March 1999 \\
\hline III & 1999 & May 14 & 12 & $\begin{array}{l}1 \times \text { progesterone }\left(\mathrm{P}_{4}\right)+4 \times \mathrm{GnRH} \\
\text { or insertion of a FSH releasing pump } \\
\text { or } 8 \times \mathrm{FSH} \text { or } 1 \mathrm{x} \text { PMSG }\end{array}$ & February - Ma \\
\hline IV & 2000 & May 16 & 20 & $\begin{array}{l}6 \times \mathrm{P}_{4}+4 \times \text { GnRH }(\text { each } 250 \mu \mathrm{g}) \\
\text { or } 8 \times \mathrm{FSH}\end{array}$ & February - March 2001 \\
\hline $\mathrm{V}$ & 2001 & May 15 & 20 & $\begin{array}{l}5 \times \mathrm{P}_{4}+4 \times \text { GnRH }(100 \mathrm{ng})+1 \times \mathrm{GnRH}(50 \mu \mathrm{g}) \\
\text { or } 10 \times \mathrm{P}_{4}+1 \times \text { PMSG }\end{array}$ & $\begin{array}{l}\text { October } 16(\mathrm{n}=2) 2001 \\
\text { or January - March }\end{array}$ \\
\hline $\mathrm{Va}$ & 2002 & April 20 & 2 & GnRH variant like 2001 , but absence of a ram & \\
\hline
\end{tabular}

Exp. I was performed on untreated ewes $(\mathrm{n}=6)$, in addition to a previous study (REHBOCK et al., 1999). It was done to characterize variation of steroid and LH levels in blood samples $(n=17)$ taken every 3 days during the anoestrous period, and some months later, during the spontaneous luteolysis within the breeding season. Exp. II had the aim to find out hormonal and clinical effects of either $5 \mathrm{ml}$ of a pheromone containing paste to simulate an extended ram contact or a single injection by $50 \mu \mathrm{g}$ of 
GnRH agonist (each group $\mathrm{n}=8$ ). Blood sampling for $\mathrm{P}_{4}$ analysis was continued every 2 to 3 days throughout d 30. Aim of Exp. III was to compare treatments by a) the combined stimulation of a single $\mathrm{P}_{4}$ injection followed by 4 times $50 \mu \mathrm{g}$ of $\mathrm{GnRH}$ (72, 75,78 , and $81 \mathrm{~h}$ later; $\mathrm{n}=3$ ), or b) 8 times FSH (8:00 and 14:00 on 4 consecutive days; $\mathrm{n}=3$ ), or c) implantation of an osmotic pump with a continuous release of FSH over 7 days $(n=3)$, or $d)$ a single injection of PMSG $(n=3)$. A fertile ram was permanently present and a single blood $\mathrm{P}_{4}$ analysis performed on $\mathrm{d} 28$ was done to monitor luteal activity. Next, effects of a previous priming by six injections of $\mathrm{P}_{4}$ followed by 4 injections of the $\mathrm{GnRH}$ agonist (each $50 \mu \mathrm{g} ; \mathrm{n}=10$ ) were compared with those of an elevated blood gonadotropin level after multiple injections of FSH or its release from an osmotic pump (each $n=5)$ or a single administration of PMSG $(n=$ 5; Exp. IV). Aim of Exp. V was to compare, besides the presence of a ram, the effects of either a combination of $\mathrm{P}_{4}$ priming (5 injections) and $\mathrm{GnRH}$ agonist $(\mathrm{G} ; \mathrm{n}=8)$ given in a modified manner as that used in Exp. IV or a combination priming (10 injections) followed by a single PMSG $24 \mathrm{~h}$ later $(\mathrm{P} ; \mathrm{n}=8)$. Four untreated ewes served as controls in studying the $\mathrm{P}_{4}$ concentration. First group received 5 injections of Gonavet ${ }^{\circledR} 72,75,78,81,84$ (in each case $100 \mathrm{ng}$ ) and $96 \mathrm{~h}(50 \mu \mathrm{g})$ after last $\mathrm{P}_{4}$. Four animals left untreated. Bleeding was performed each experimental day at 8:00 throughout day 16 and additionally immediately before each injection of small dose of Gonavet ${ }^{\circledR}$ and $2 \mathrm{~h}$ after large peptide amount. Ultrasonography were used as a direct and $\mathrm{P}_{4}$ analysis in blood samples as a indirect test for pregnancy on day 62. An identical regime of the combination priming and GnRH agonist, but in absence of a ram, was applicated in a repetition performed in $2002($ Exp. Va; $\mathrm{n}=2)$.

\section{Analytical methods}

Changes affected by different hormonal treatments were studied by a combination of methods, i.e. the use of a fertile ram to mark females exhibiting oestrous signs and ultrasonography with the device SSD 500 (Aloka, Japan) equipped with 5.0 or 7.5 $\mathrm{MHz}$ probes to monitor the function of ovary and presence of a fetus, respectively. Specific and sensitive electrochemiluminescence-immunoassays applied for the gonadotropins LH (sandwich-type ECLIA) and FSH (competitive ECLIA), and $\left[{ }^{3} \mathrm{H}\right]-$ RIA applied for the steroid hormones $\mathrm{P}_{4}$ and estradiol-17 $\beta\left(\mathrm{E}_{2}\right)$ were described elsewhere with all relevant characteristics including sensitivities and intra- and interassay variation (SCHNEIDER et al., 2002). Shortly, the non-radioactive LH assay uses a monoclonal antibody (mAB) against bovine LH (mAB 518 B7) which was labelled by a special ruthenium-compound according to the recommendation of IGEN (Gaithersburg, PA, USA), a standard preparation of bLH (Biotrend, Cologne, Germany), a polyclonal AB against bLH raised in rabbits (KANITZ et al., 1990), and a goat-anti-rabbit-AB coupled to magnetic beads (Dynal, Oslo, Norway) for the separation of bound and free fraction. The FSH assay was constructed by an ovine standard (oFSH; AFP 7571 A) which was labelled in a similar way as described for $\mathrm{LH}$ and a polyclonal $\mathrm{AB}$ against oFSH raised in rabbits (NIDDK-oFSH-1 AB), and the coupled second AB called already. Measurement of ECLIA methods was performed in the ORIGEN® 1.5-instrument (IGEN). 


\section{Statistical calculations}

Sampling frequencies were a compromise between limitations by extensive conditions for sheep keeping and minimum needs to characterize specific reproductive processes. For each variant of the hormonal treatment, means \pm S.D. were calculated. In this study, definitions for terms relating to gonadotropin concentrations are used as previously (SCHNEIDER et al., 2002): pulse - an increase in concentrations that lasts a short time (e.g. 10-60 min), basal concentrations - levels that underlie the pulses; surge - an increase in concentrations of long duration equivalent to the duration of many pulses.

\section{Results}

In Exp. I, mean concentrations of $\mathrm{E}_{2}, \mathrm{P}_{4}$ and $\mathrm{LH}$ during the early non-breeding period (March to May) reflected the depressed cyclic function, however, we found some individual differences. Low $\mathrm{E}_{2}$ (data not shown) and $\mathrm{P}_{4}$ levels measured in all samples of the first trial (Exp. I) indicated the absence of mature follicles and functional corpora lutea, respectively, in all 6 ewes, whereas the absolute height of mean LH was clearly influenced by individual $0-4$ pulses during the sampling period (Fig. 1). In an

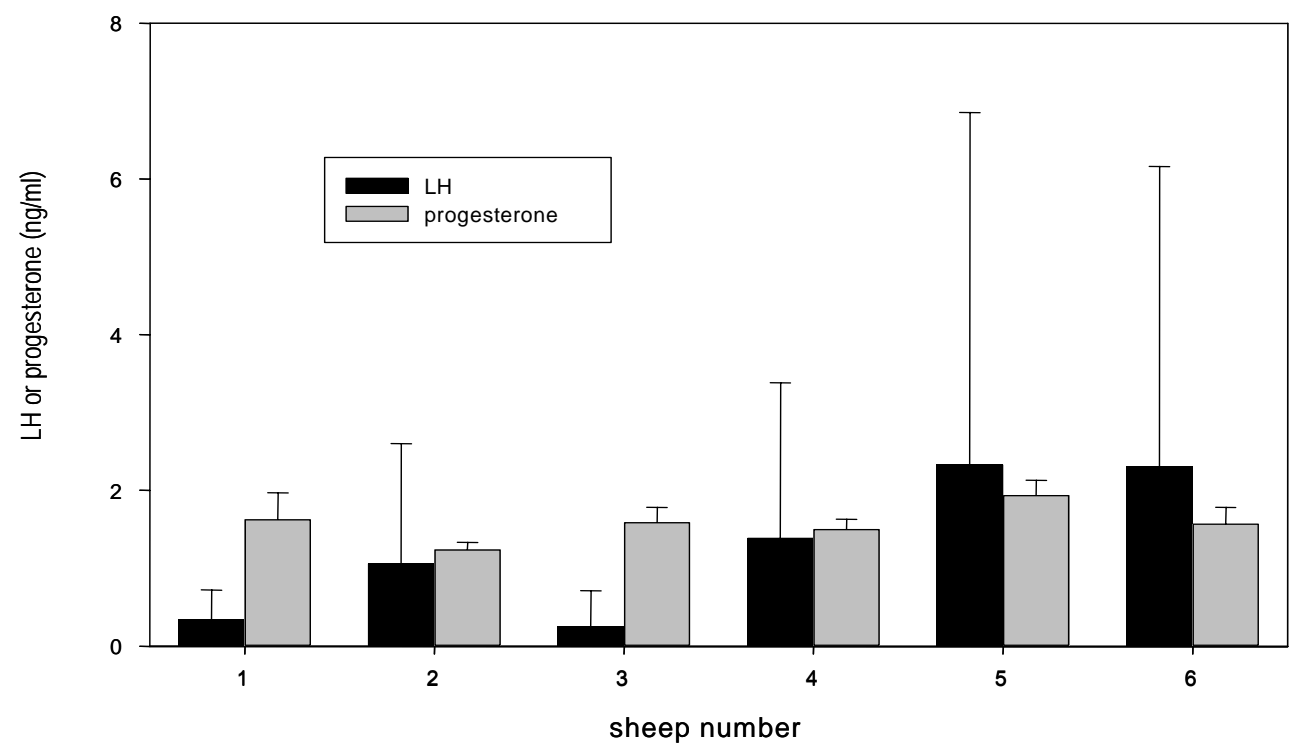

Fig. 1: Mean blood plasma concentrations of progesterone and LH $(\mathrm{ng} / \mathrm{ml})$ of Blackhead ewes $(\mathrm{n}=6)$ during the early non-breeding season (March - May) (Mittlere Konzentrationen von Progesteron and LH im Blutplasma $(\mathrm{ng} / \mathrm{ml})$ von Schwarzköpfigen Fleischschafen $(\mathrm{n}=6)$ während des frühen saisonalen Anöstrus (März - Mai))

additional sampling series throughout September/October, the preovulatory LH surge began approximately $58 \mathrm{~h}$ after reaching basal $\mathrm{P}_{4}$ concentrations and increased to more than $40 \mathrm{ng} / \mathrm{ml}$ plasma within $4 \mathrm{~h}$ (Fig. 2) which was 8 to 10 times higher than the amplitudes of the described pulses. A single blood sample from each animal taken on day 1 8:00 of Exp. II, before any treatment, showed low levels of $\mathrm{P}_{4}, \mathrm{LH}$ and FSH $(0.88 \pm 0.12 ; 2.2 \pm 2.6$ and $3.20 \pm 2.15 \mathrm{ng} / \mathrm{ml}$, respectively; Fig. 3$)$. The administration of $50 \mu \mathrm{g}$ of Gonavet ${ }^{\circledR}$ induced a significant release of both gonadotropins within one hour which was higher for $\mathrm{LH}$, but finished for both within $4 \mathrm{~h}$ after injection, whereas the $\mathrm{P}_{4}$ level left unchanged over the sampling period. The application of the pheromone-containing paste did not influence the secretion of LH or FSH (data not 


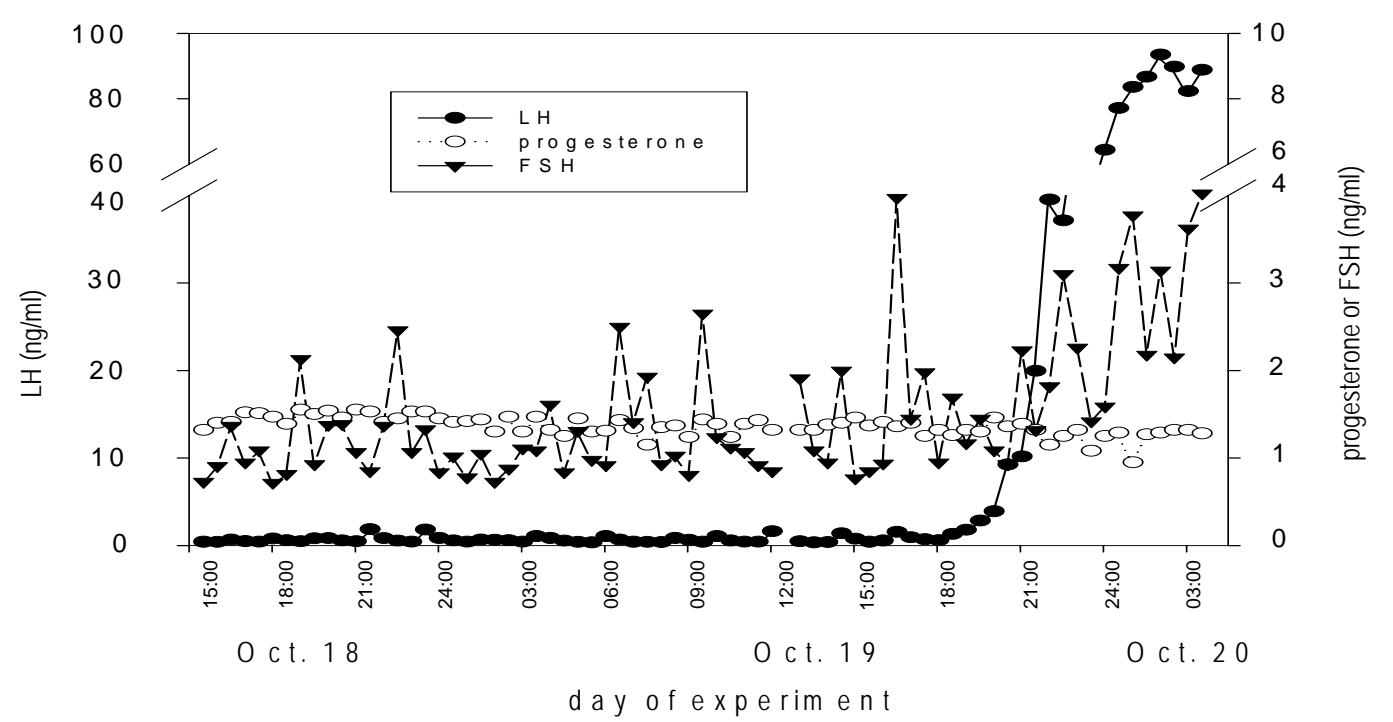

Fig. 2: Blood plasma concentrations of progesterone, LH and FSH (ng/ml) of a Blackhead ewe during the spontaneous luteolysis (Blutplasmakonzentrationen von Progesteron, LH und FSH (ng/ml) bei einem Schwarzköpfigen Fleischschaf während der spontanen Luteolyse)

shown). In 12 samples taken additionally from each ewe during further 4 weeks the $\mathrm{P}_{4}$ concentration was lower than $1.2 \mathrm{ng} / \mathrm{ml}$ and indicating the absence of active corpora lutea.

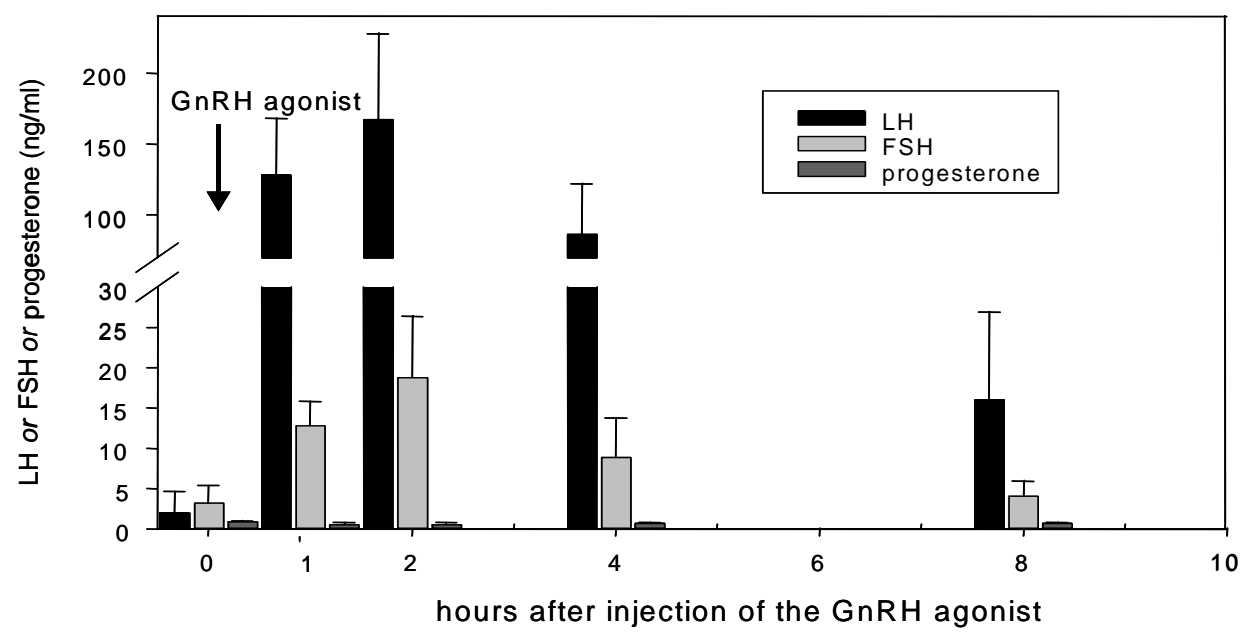

Fig. 3: Effects of a GnRH agonist on the release of progesterone, LH and FSH (ng/ml) of anoestrous Blackhead ewes $(n=8)$ (Beeinflussung der Freisetzung von Progesteron, LH und FSH (ng/ml) durch einen GnRHAgonisten in anöstrischen Schwarzköpfigen Fleischschafen $(\mathrm{n}=8))$

Oestrus signs of different strength were observed both in FSH groups and in PMSG group, but not in the $\mathrm{P}_{4}$-primed GnRH group (Exp. III). Priming resulted in an increase in blood $\mathrm{P}_{4}$ from $0.67 \pm 0.16 \mathrm{ng} / \mathrm{ml}$ before treatment to $1.53 \pm 0.40 \mathrm{ng} / \mathrm{ml} 24 \mathrm{~h}$ later, however, concentrations of next 2 days each analysed at 8:00 am (1.08 \pm 0.52 and 0.89 $\pm 0.36 \mathrm{ng} / \mathrm{ml}$ ) indicated the diminishing of $\mathrm{P}_{4}$ from blood given only once. The $\mathrm{P}_{4}$ level (Fig. 4) was low in all 8:00 samples of PMSG-treated animals, and only moderately elevated to $1.25 \pm 0.33 \mathrm{ng} / \mathrm{ml}$ on day 6 in ewes treated by continuous FSH, but multiple FSH injections induced an increase in 2 from 3 animals between days 2,5 and $7(0.70 \pm 0.21,1.05 \pm 0.18$, and $3.01 \pm 0.38 \mathrm{ng} / \mathrm{ml}$, respectively) which could indicate previous ovulations. However, results from $\mathrm{P}_{4}$ determinations performed during the 
following period could not confirm the successful induction of luteal phases of normal length (data not shown).

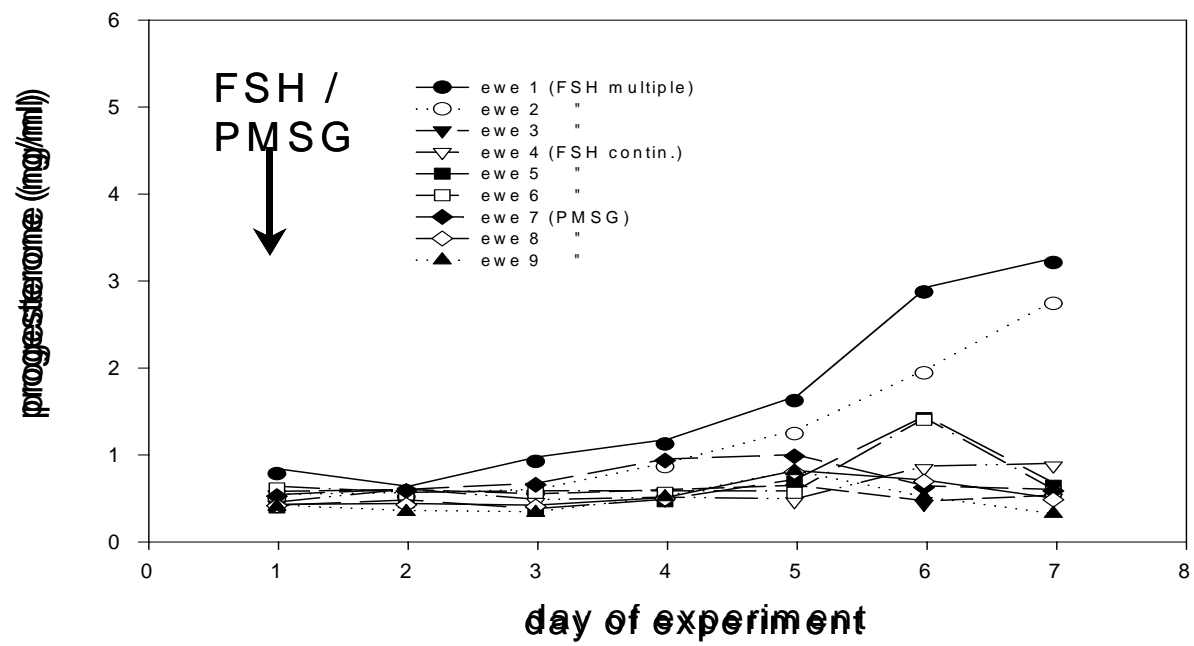

Fig. 4: Effect of exogenous FSH or PMSG on progesterone plasma levels ( $\mathrm{ng} / \mathrm{ml})$ of Blackhead ewes $(\mathrm{n}=9)$ during the non-breeding season (Beeinflussung der Progesteronkonzentration im Blutplasma (ng/ml) von Schwarzköpfigen Fleischschafen $(\mathrm{n}=9)$ durch exogenes FSH oder PMSG)

In Exp. IV, the mean $\mathrm{P}_{4}$ level of all ewes $(\mathrm{n}=20)$ before any treatment was $0.95 \pm 0.21$ $\mathrm{ng} / \mathrm{ml}$. Treatment by exogenous $\mathrm{P}_{4}$ and GnRH agonist induced various changes in blood levels of $\mathrm{P}_{4}, \mathrm{LH}$ and FSH analysed in 5 ewes by repeated sampling (Table 2),

Table 2

Progesterone $\left(\mathrm{P}_{4}\right)$, LH and FSH plasma concentrations $(\mathrm{ng} / \mathrm{ml})$ in anoestrous ewes $(\mathrm{n}=5)$ after treatment by exogenous $\mathrm{P}_{4}$ and a GnRH agonist (GnRH; EXP. IV) (Progesteron $\left(\mathrm{P}_{4}\right)$, LH und FSH Plasmakonzentrationen $(\mathrm{ng} / \mathrm{ml})$ in anöstrischen Schafen $(\mathrm{n}=5)$ nach Behandlung mit exogenem $\mathrm{P}_{4}$ und einem GnRH-Agonist $(\mathrm{GnRH})$; Exp. IV)

\begin{tabular}{|c|c|c|c|c|c|c|c|c|}
\hline \multirow[t]{2}{*}{ Day } & \multirow[t]{2}{*}{ Time } & \multirow[t]{2}{*}{ Measure } & \multicolumn{2}{|c|}{$\mathrm{P}_{4}$} & \multicolumn{2}{|c|}{$\mathrm{LH}$} & \multicolumn{2}{|c|}{ FSH } \\
\hline & & & Mean & S.D. & Mean & S.D. & Mean & S.D. \\
\hline 1 & $08: 00$ & $\overline{\mathrm{P}_{4}}$ & 1.03 & 0.22 & 0.96 & 0.23 & 1.30 & 0.33 \\
\hline 2 & 08:00 & $\mathrm{P}_{4}$ & 1.72 & 0.24 & 1.64 & 0.41 & 1.91 & 0.41 \\
\hline \multirow[t]{2}{*}{3} & 08:00 & $\mathrm{P}_{4}$ & 2.31 & 0.96 & 1.53 & 0.36 & 1.35 & 0.29 \\
\hline & $14: 00$ & & 3.12 & 0.96 & 0.88 & 0.62 & 1.34 & 0.50 \\
\hline \multirow[t]{2}{*}{4} & 08:00 & $\mathrm{P}_{4}$ & 3.62 & 2.07 & 1.48 & 0.43 & 1.79 & 0.44 \\
\hline & $14: 00$ & & 3.34 & 0.43 & 0.76 & 0.55 & 1.59 & 0.48 \\
\hline \multirow[t]{2}{*}{5} & 08:00 & $\mathrm{P}_{4}$ & 2.42 & 0.23 & 1.16 & 0.58 & 1.57 & 0.39 \\
\hline & $14: 00$ & & 3.44 & 0.77 & 1.22 & 0.64 & 1.63 & 0.42 \\
\hline \multirow[t]{2}{*}{6} & 08:00 & $\mathrm{P}_{4}$ & 2.62 & 0.61 & 1.48 & 0.59 & 2.02 & 0.53 \\
\hline & $14: 00$ & & 3.57 & 0.63 & 1.57 & 0.47 & 1.95 & 0.24 \\
\hline \multirow[t]{12}{*}{7} & $08: 00$ & GnRH & 2.08 & 0.27 & 1.75 & 1.51 & 2.10 & 1.32 \\
\hline & 09:00 & & 2.02 & 0.38 & 34.32 & 0.33 & 3.40 & 1.66 \\
\hline & $10: 00$ & & 1.90 & 0.43 & 87.90 & 51.06 & 9.81 & 3.41 \\
\hline & 11:00 & GnRH & 1.21 & 0.33 & 115.92 & 36.48 & 12.63 & 4.48 \\
\hline & $12: 00$ & & 1.96 & 0.40 & 76.14 & 34.93 & 9.44 & 5.39 \\
\hline & $13: 00$ & & 2.08 & 0.35 & 57.11 & 28.17 & 6.04 & 0.92 \\
\hline & $14: 00$ & GnRH & 2.00 & 0.26 & 26.80 & 26.22 & 4.35 & 1.57 \\
\hline & $15: 00$ & & 1.89 & 0.38 & 22.93 & 12.41 & 4.05 & 1.86 \\
\hline & $16: 00$ & & 1.92 & 0.41 & 15.55 & 11.32 & 2.67 & 0.64 \\
\hline & $17: 00$ & GnRH & 2.04 & 0.18 & 10.54 & 8.97 & 2.31 & 0.82 \\
\hline & $18: 00$ & & 1.88 & 0.27 & 7.04 & 5.76 & 1.87 & 1.04 \\
\hline & $19: 00$ & & 1.82 & 0.22 & 6.32 & 5.21 & 1.71 & 0.60 \\
\hline 9 & 08:00 & & 1.16 & 0.19 & 0.68 & 0.57 & 1.94 & 0.45 \\
\hline
\end{tabular}


e.g. the $\mathrm{P}_{4}$ concentration was elevated during the whole priming period and dropped moderately after the $6^{\text {th }}$ injection of $\mathrm{P}_{4}$ and 4 times GnRH agonist within 48 $\mathrm{h}$ to $1.16 \pm 0.19 \mathrm{ng} / \mathrm{ml}$. In contrary with this, the mean $\mathrm{LH}$ level was between $0.76 \pm$ 0.55 and $1.75 \pm 1.51 \mathrm{ng} / \mathrm{ml}$ in 8:00 and 14:00 samples from each day during priming, whereas the FSH level was in a comparable range $(1.34 \pm 0.50$ and $2.10 \pm 1.32 \mathrm{ng} / \mathrm{ml}$, respectively). The $1^{\text {st }}$ injection of $\mathrm{GnRH}$ agonist elevated both gonadotropin levels within some minutes, however, the increase in FSH was weaker than that of LH. Results showed that neither the $2^{\text {nd }}$ nor the $3^{\text {rd }}$ and the $4^{\text {th }}$ injection of agonist were able to stimulate the further secretion of both hormones. Plasma concentrations reached nearly the pre-treatment levels at the end of sampling (Table 2). Endocrine results of the other treatment group demonstrated a steep increase in FSH after each of the eight injections of Ovagen ${ }^{\mathrm{TM}}$ by the factor 4 to 6 , but the elevation was kept only for approximately $12 \mathrm{~h}$ (data not shown). We found in 2 from 5 treated ewes an increase in plasma $\mathrm{P}_{4}$ detectable already $24 \mathrm{~h}$ after last injection and reaching 3.6 and $4.5 \mathrm{ng} / \mathrm{ml}$, respectively, two days later. Further testation of plasma $\mathrm{P}_{4}$ one and two weeks later resulted in basal levels like before treatment. Concentrations of $\mathrm{P}_{4}$ were low in group $\mathrm{G}$ of Exp. $\mathrm{V}$ at begin of agonist administration but, as expected, not immediately before PMSG injection in another treatment group $(0.93 \pm 0.16$ versus $1.64 \pm 0.17$ ng/ml; Fig.5).

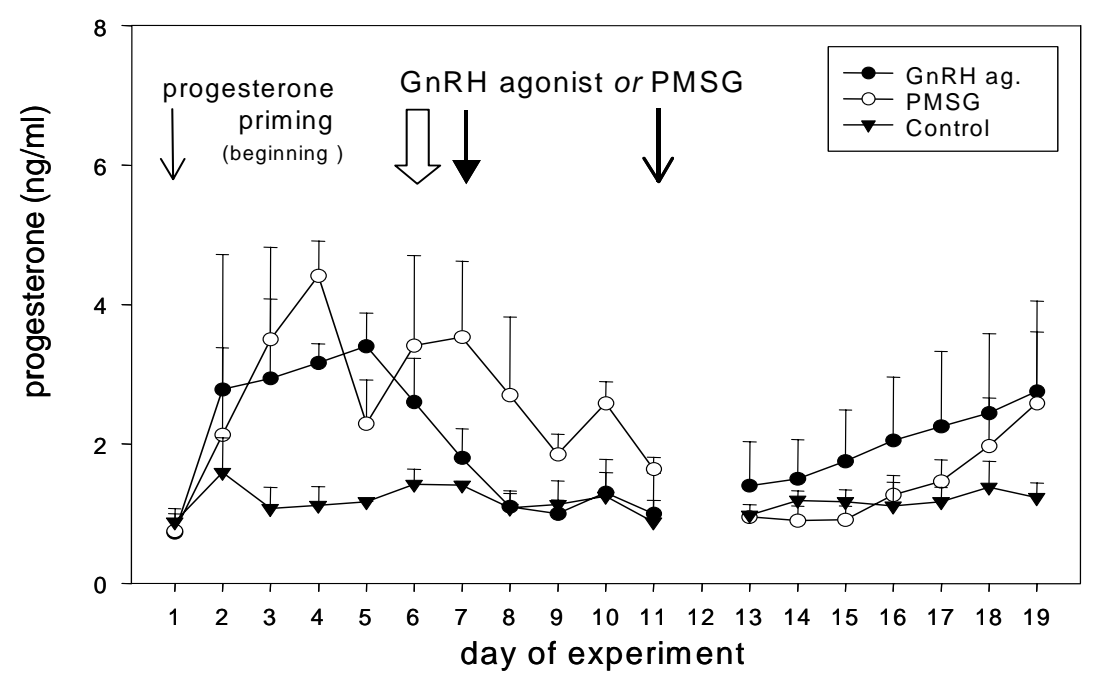

Fig. 5: Secretion of progesterone (ng/ml) during anoestrus after a previous progesterone priming and sequential treatment by a GnRH agonist $(n=8)$, single PMSG injection $(n=8)$, and in controls $(n=4)$, Exp. V (Progesteronsekretion $(\mathrm{ng} / \mathrm{ml})$ während des Anöstrus nach vorherigem Progesteron-Priming und sequentieller Behandlung mit einem GnRH-Agonisten $(n=8)$, einer einzelnen PMSG-Injektion $(n=8)$ und in Kontrolltieren (n =4), Exp. V)

As shown in Fig. 6, gonadotropin levels were not affected by first five injections of GnRH agonist (low dosage) but increased steeply after the $6^{\text {th }}$ (high dosage). In both treatment groups, some ewes showed marks by the ram, however, there was a difference between GnRH agonist and PMSG treatment (2 from 8 versus 7 from 8 animals). Analysis of $\mathrm{P}_{4}$ levels revealed an increase in 5 from 7 and 6 from 8 , respectively, ewes throughout first after treatment-week (Fig. 5), whereas the steroid concentration left unchanged in controls $(n=4)$. 


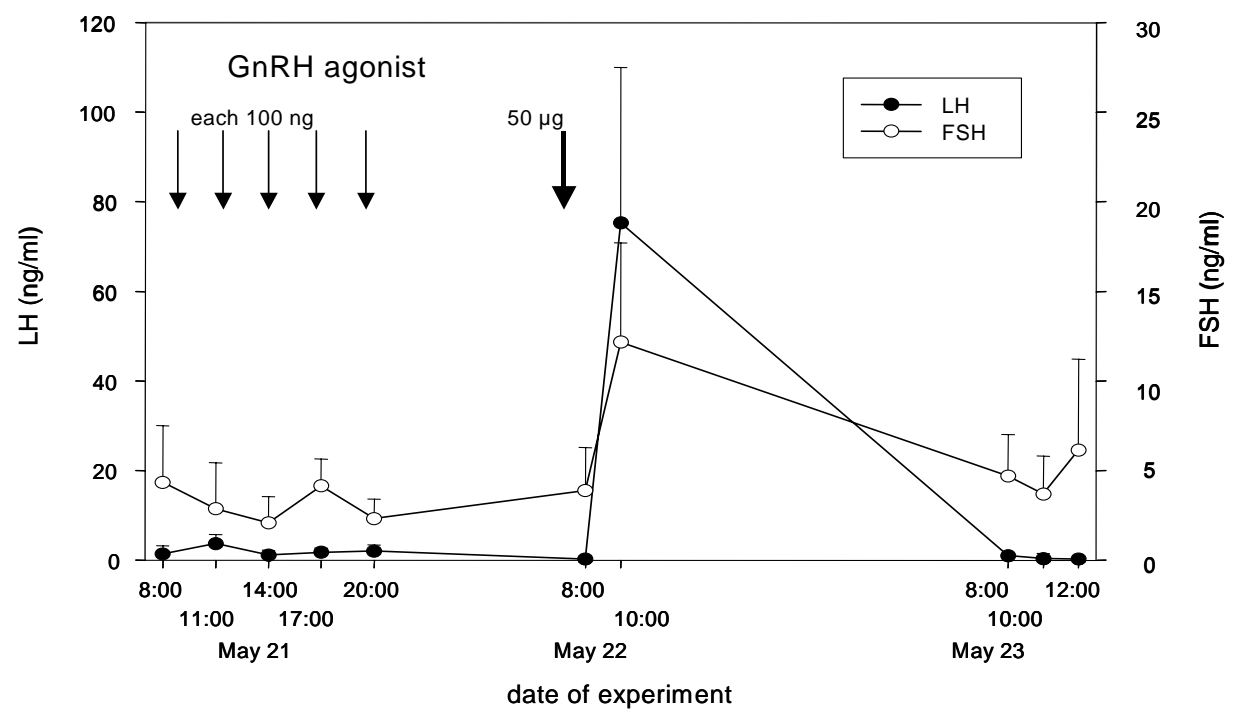

Fig. 6: Secretion of LH and FSH $(n g / m l)$ of anoestrous ewes $(n=8)$ during the treatment period with a GnRH agonist $(5$ times $100 \mathrm{ng}+$ once $50 \mu \mathrm{g}$ ) after previous priming (Sekretion von $\mathrm{LH}$ und $\mathrm{FSH}(\mathrm{ng} / \mathrm{ml}$ ) in anöstrischen Schafen ( $\mathrm{n}=8)$ während der Behandlung mit einem GnRH-Agonist (5x $100 \mathrm{ng}+1$ x $50 \mu \mathrm{g})$ nach vorherigem Priming)

Two months after hormone substitution, animals from both treatment groups were found to be pregnant according to the result of ultrasonography (3 and 7, respectively, and further 2 ewes questionable; Fig. 7).

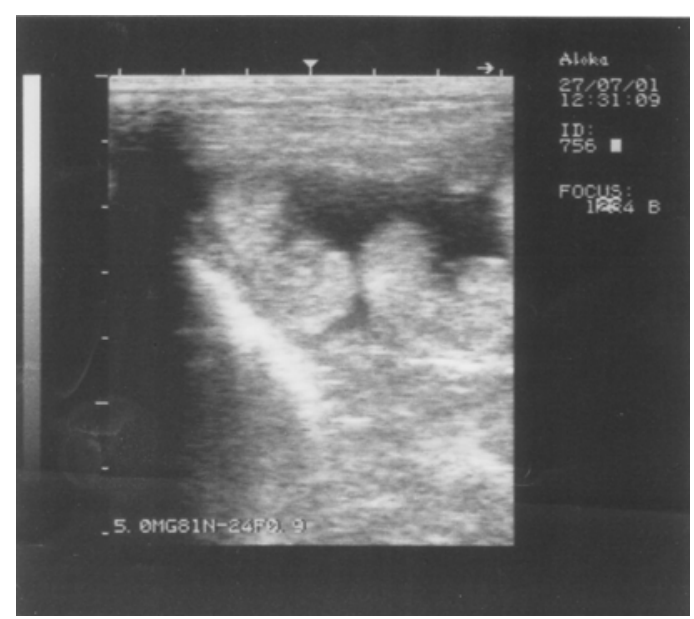

Fig. 7: Ultrasonographic detection of twins in a Blackhead ewe on day 62 of pregnancy after combined treatment with priming and PMSG during anoestrus (Ultraschallnachweis von Zwillingen bei einem Schwarzköpfigen Fleischschaf am 62. Trächtigkeitstag nach kombinierter Behandlung mit Priming and PMSG während des Anöstrus)

Elevated $\mathrm{P}_{4}$ concentrations in blood samples taken at the same time confirmed this result indicating the presence of an active corpus luteum in 3 animals $(>3.0 \mathrm{ng} / \mathrm{ml})$ and were questionable in another $4(1.1-1.6 \mathrm{ng} / \mathrm{ml})$. Ewes were spent to the stall one month before the expected parturition. A male lamb was born after priming and GnRH agonist treatment, and a pair of twins after priming and PMSG (Fig. 8). 


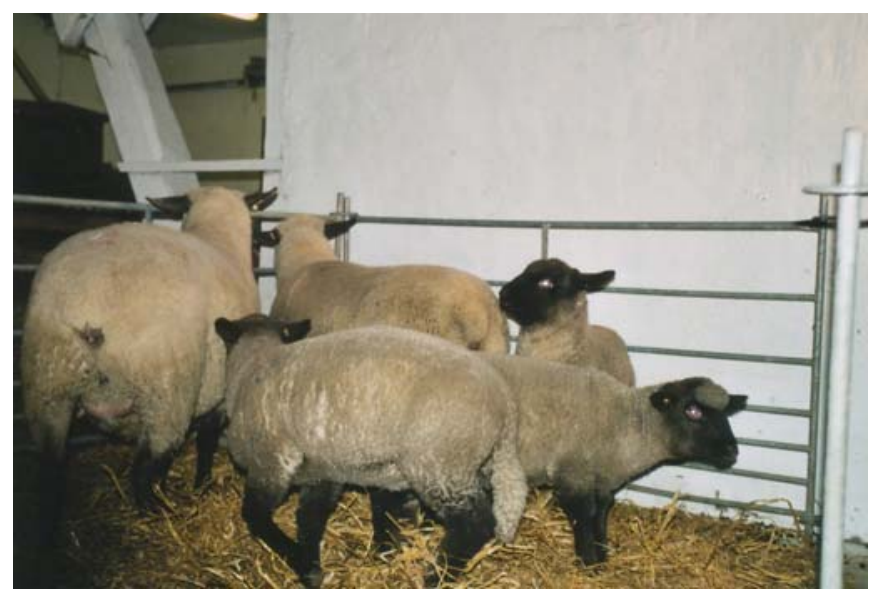

Fig. 8: Three months old lambs (single + twins) with their mothers born in October after hormonal treatment during anoestrus (Drei Monate alte Lämmer (Einzeltier und Zwillingspärchen) mit ihren Müttern, geboren im Oktober nach hormoneller Behandlung im Anöstrus)

The identical treatment of 2 further ewes by the combination priming and sequential GnRH agonist one year later (Exp. Va), but in absence of a ram, confirmed the results of previous experiments, e.g. comparable levels of gonadotropins (Fig. 9) and $\mathrm{P}_{4}$ which were lower than $2 \mathrm{ng} / \mathrm{ml}$ before treatment, increased after exogenous $\mathrm{P}_{4}$ to 3 $5 \mathrm{ng} / \mathrm{ml}$, and luteal phases with a length of 7 - 9 days after previous ovulations.
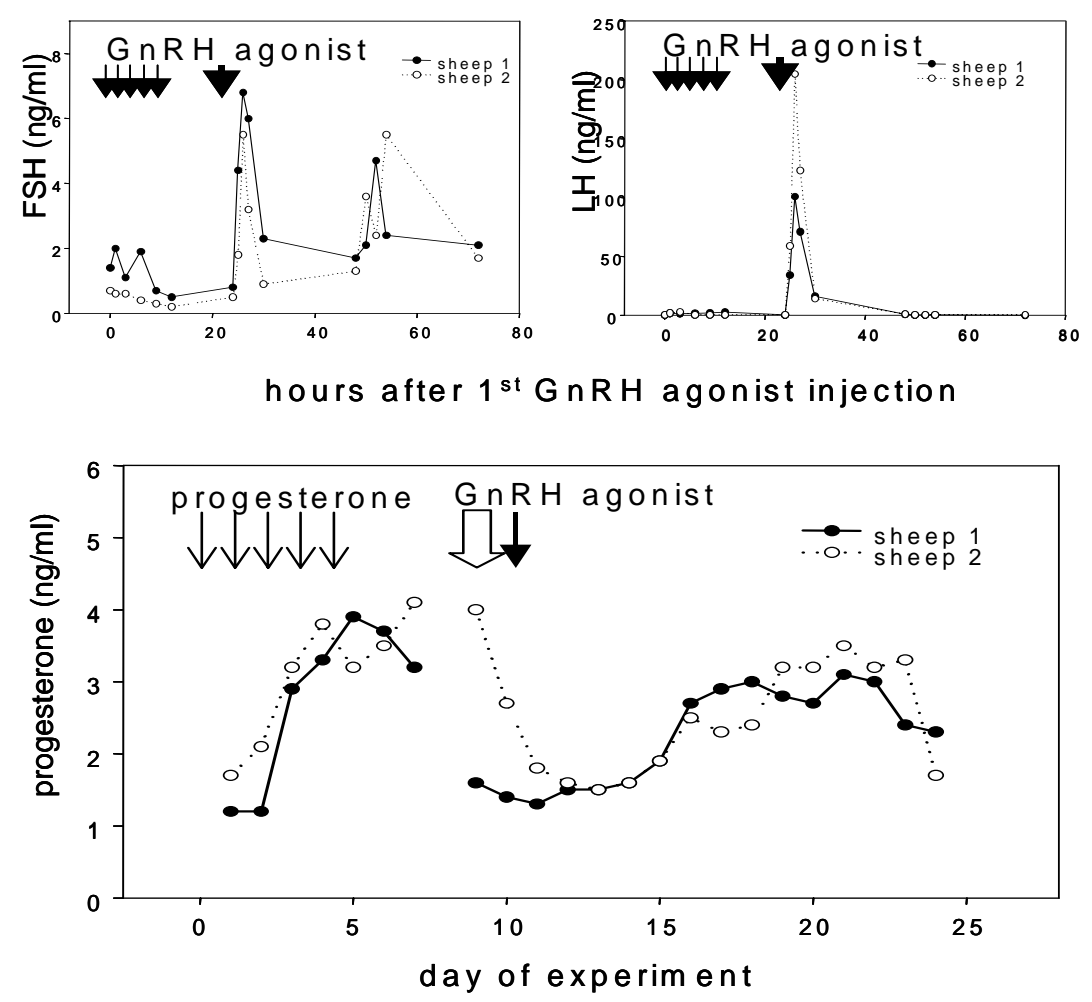

Fig. 9: Individual LH, FSH and progesterone secretion $(\mathrm{ng} / \mathrm{ml})$ of Blackhead ewes $(\mathrm{n}=2)$ during the sequential treatment with the GnRH agonist in the early non-breeding period (April) (Individuelle LH-, FSH- und Progesteron-Sekretion (ng/ml) von Schwarzköpfigen Fleischschafen $(\mathrm{n}=2)$ während der sequentiellen Behandlung mit dem GnRH-Agonist im frühen Anöstrus (April)) 
In the sum, our experiments showed that only a combination of $\mathrm{P}_{4}$ priming and exogenous $\mathrm{GnRH} /$ gonadotropin may suitable to advance the begin of the breeding season in the Blackhead by some months. The reason is seen in the need of an endocrine situation which is similar under all relevant aspects with that of the oestrous cycle.

\section{Discussion}

A continuous production of lambs nearly over the year is only possible in the Blackhead sheep like other breeds with a seasonal reproductive function by a combination of different measures like intensive selection and introduction of a ram to the flock. Pheromones stored in the wool, wax and urine of ram are effective to increase ovarian activity (KAULFUSS et al., 1997; REKWOT et al., 2001; ZUNIGA et al., 2001), however, it seems to be impossible to obtain fertile cycles without an additional hormonal treatment under conditions of the extensive sheep keeping, e.g. for cultivation of landscape. It was, therefore, the aim of our study to develop a complex treatment regime that considers as well the main endocrine interrelationships during seasonal and nonseasonal period as practical regulations. Cyclic oestrus behaviour usually appears at the end of summer or the beginning of autumn and finishes in winter or at the very beginning of spring (GALLEGOS-SANCHEZ et al., 1998). Considering a 5months-duration of pregnancy in sheep the lambing period is concentrated in months December to February. There are breed-depending differences and, moreover, other factors exist that may influence time of year when ewes are sexually active or inactive. Although both small and medium-sized follicles and low levels of peripheral plasma $\mathrm{P}_{4}$ levels have been detected (KAULFUSS et al., 1997; REHBOCK et al., 1999; BARTLEWSKI et al., 2000), a limitation of ovarian activity which is characterized by the absence of pre-ovulatory follicles with normal secretory rate is observed (SOUZA et al., 1996). The reason can be seen in day-light affected changes of the secretion of melatonin which amplifies the negative feedback response of the hypothalamus to ovarian $\mathrm{P}_{4}$. An infrequent $\mathrm{GnRH}$ and $\mathrm{LH}$ pulse rate of 1 per 6 $12 \mathrm{~h}$ in anoestrus results compared with 1 per $30-60 \mathrm{~min}$ in the follicular phase of the oestrous cycle (GALLEGOS-SANCHEZ et al., 1998; O'CALLAGHAN, 1999). The only limiting factor for $\mathrm{LH}$ secretion is, therefore, infrequent $\mathrm{GnRH}$ stimulation (GHOSH et al., 1996) compared with the situation in cyclic ewes (KARSCH et al., 1997). Moreover, there is a changed LH reception by ovarian cells because differences have been observed in the occurrence of splice variants of mRNA encoding the LH receptor between follicles taken throughout season or the anoestrous period (ABDENNEBI et al., 2002), whereas all the forms of the bovine LH receptor mRNA increased in a coordinated manner during the development of cyclic corpus luteum (KAWATE and OKUDA, 1998). The simplest variant to overcome the anoestrous period by exogenous hormones seems to mimic a short-day period of year by melatonin application. Experimental data from the literature showed that exogenous melatonin give results that show a high degree of variation related to breed, management system, and environmental and physiological factors. A melatonin treatment may have, therefore, a restrained potential to shorten considerably the anoestrous period and, parallel with that, improve reproductive performance (HARESIGN, 1992; BRUNET et al., 1995; ZUNIGA et al., 2002). Long-term results of melatonin application have yet to be fully evaluated, but a refractoriness of 
treatment can not excluded, because animals seem to need a period of long days (ARENDT, 1998). Following the route of melatonin effect across endogenous opiate peptides (EOP) of brain, further possibilities may arise from an intervention in that mechanism. Really, it was found that administration of naloxone, an EOP antagonist, revealed an earlier onset of oestrus, increased length and earlier LH surge in anoestrous ewes hormonally treated for the induction of cycles (FUENTES et al., 2001). Next, it is well-known that administration of GnRH or one of its potent agonists induces an immediate LH release, however, the resulting surge should have an appropriate shape like the endogenous GnRH maximum. In cyclic ewes, the onset of the LH surge during the follicular phase is coincident with the initiation of a massive and sustained increase in GnRH secretion which continues well beyond the surge of LH and its amplitude may exceed that needed to generate the LH surge (BOWEN et al., 1998). The importance of prolonged GnRH secretion is seen in the maintenance of receptive behaviour, prolonging the initial triggering effect of $\mathrm{P}_{4}$ (CARATY et al., 2002). Blockade of GnRH action, e.g. by a GnRH antagonist, terminates the further release of LH (EVANS et al., 1996). An inadequate treatment with exogenous GnRH may, therefore, unfavourably influence the number and quality of pituitary GnRH receptors (SCHNEIDER et al., 2002) or ovarian LH receptors (ABDENNEBI et al., 2002), the occurrence of oestrus signs or the corpus luteum development. Thus, GnRH given in a pulsatile manner, e.g. every $2 \mathrm{~h}$ for $24-48 \mathrm{~h}$ in the non-breeding period induced the LH surge and ovulation, but these effects were often followed with a shortened luteal phase (BASIOUNI et al., 1996). Unsatisfying results of numerous studies demonstrate the complexity of the neuroendocrine regulation of reproductive processes, thus, it seems to be important to begin each treatment out-of-season with a $\mathrm{P}_{4}$ priming, i.e. a pre-treatment with $\mathrm{P}_{4}$ or synthetic progestagens (DANIEL et al., 2001). Aims of this step are to mimic the luteal phase of the oestrous cycle and the existence of the negative feedback of $\mathrm{P}_{4}$ which is responsible for the inhibition of LH pulse frequency (GOODMAN et al., 1995) and to intensify oestrus signs. There are large differences in the length and dose of $\mathrm{P}_{4}$ administration and the distance to further treatments that should enable the development of the positive $E_{2}$ feedback on hypothalamus and pituitary that results from a decrease in the response of the pituitary to GnRH and an inhibition of the GnRH pulse size (EVANS et al., 1994; GOODMAN et al., 1995). Elevated endogenous $\mathrm{P}_{4}$ may directly interfere with the activation of $\mathrm{E}_{2}$ responsive neural systems to block both surges (RICHTER et al., 2002), although the $\mathrm{E}_{2}$ signal is relatively short $(7-14 \mathrm{~h})$ and may only effective during the pre-surge period. A limitation of the usefulness of $\mathrm{E}_{2}$ measurements in sheep under practical conditions can be derived. On the other hand, EVANS et al. (1996) have found that development and progression of the preovulatory LH surge in sheep depend upon GnRH stimulation throughout its entire time course. In literature, priming was performed by different ways, e.g. a single $\mathrm{P}_{4}$ injection before a $\mathrm{GnRH}$ treatment was not able to eliminate defective luteal function through early stages of follicle development (BASIOUNI et al., 1996; KHALID et al., 1997). A short-term priming, i.e. a treatment over a period of 3 - 6 days (KNIGHTS et al. 2001) has the advantage of allowing more flexibility in length of priming and more flexibility in treatment protocols under field conditions (UNGERFELD and RUBIANES, 1999). Going-on in the route of melatonin action, priming and exogenous gonadotropins of different origin were used by numerous researchers (e.g. UNGERFELD and RUBIANES, 1999; 
KNIGHTS et al., 2001; STENBAK et al., 2001). Results by others groups demonstrated he usefulness of different combinations of hormones to overcome the blockade of ovarian function in anoestrous ewes. In our study which was tightly accompanied by a complex of control measures, healthy lambs were born in time in both treatment groups. This result has demonstrated that a moderate stimulation of anoestrous ewes by exogenous hormones is able to advance the begin of the breeding season thus significantly extending the period for lamb production. Further studies, however, are necessary to optimise the hormonal treatment and to combine it with measures of keeping and breeding.

\section{Acknowledgements}

The authors thank M. KHALID (Loughborough, UK), R.J. SCARAMUZZI (London, UK) and W. ZUPP (Dummerstorf, Germany) for valuable hints, J.F. ROSER (Davis, CA, USA) for the mAB against b-LH and A.F.P. PARLOW (UCLA) and S. RAITI (NHPP) for providing LH and FSH reagents. They are grateful to the State Care Farm Dishley Mecklenburg-Vorpommern for providing the experimental possibilities and to E. HONIG, U. ANTKEWITZ and S. RODEWALD for their excellent technical assistance.

\section{References}

ABDENNEBI, L.; LESPORT, A.S.; REMY, J.J.; GREBERT, D.; PISSELET, C.; MONNIAUX, D.; SALESSE, R.:

ARENDT, J.:

Differences in splicing of mRNA encoding LH receptor in theca cells according to breeding season in ewes. Reproduction 123 (2002), 819-825

Melatonin and the pineal gland: influence on mammalian seasonal and circadian physiology. Reviews of Reproduction 3 (1998), 13-22

BARTLEWSKI, P.M.; VANDERPOL, J.; BEARD, A.P.; COOK, S.J.; RAWLINGS, N.C.:

Ovarian antral follicular dynamics and their associations with peripheral concentrations of gonadotropins and ovarian steroids in anoestrous Finnish Landrace ewes. Anim. Reprod. Sci. 58 (2000), 273-291

BASIOUNI, G.F.; KHALID, M.; HARESIGN, W.:

Effect of bovine follicular fluid treatment and progesterone priming on luteal function in GnRH-treated seasonally anoestrous ewes. Anim. Sci. 62 (1996), 443-450

BOWEN, J.M.; DAHL, G.E.; EVANS, N.P.; THRUN, L.A.; WANG, Y.; BROWN, M.B.; KARSCH, F.J.: Importance of the gonadotropin-releasing hormone $(\mathrm{GnRH})$ surge for the induction of the preovulatory luteinizing hormone surge of the ewe: dose-response relationship and excess of GnRH. Endocrinology 139 (1998), 588-595

BRUNET, A.G.; LOPEZ SEBASTIAN, A.; PICAZO, R.A.; CABELLOS, B.; GODDARD, S.: Reproductive response and LH secretion in ewes treated with melatonin implants and induced to ovulate with the ram effect. Anim. Reprod. Sci. 39 (1995), 23-34

CARATY, A.; SKINNER, D.C.:

Progesterone priming is essential for the full expression of the positive feedback effect of estradiol in inducing the preovulatory gonadotropin-releasing hormone surge in the ewe. Endocrinology 140 (1999), 165-170

CARATY, A.; DELALEU, B.; CHESNEAU, D.; FABRE-NYS, C.:

Sequential role of E2 and GnRH for the expression of estrous behavior in ewes. Endocrinology 143 (2002), 139-145

DANIEL, J.A.; STERLE, S.W.; McFADIN-BUFF, E.L.; KEISLER, D.H.:

Breeding ewes out-of-season using melengestrol acetate, one injection of progesterone, or a controlled internal drug releasing device. Theriogenology 56 (2001), 105-110 
EVANS, N.P.; DAHL, G.E.; GLOVER, B.H.; KARSCH, F.J.:

Central regulation of pulsatile gonadotropin-releasing hormone $(\mathrm{GnRH})$ secretion by estradiol during the period leading up to the preovulatory GnRH surge in the ewe. Endocrinology 134 (1994), 18061811

EVANS, N.P.; DAHL, G.E.; CARATY, A.; PADMANABHAN, V.; THRUN, L.A.; KARSCH, F.J.:

How much of the gonadotropin-releasing hormone $(\mathrm{GnRH})$ surge is required for generation of the luteinizing hormone surge in the ewe? Duration of the endogenous GnRH signal. Endocrinology 137 (1996), 4730-4737

FUENTES, V.O.; SANCHEZ, V.; ROSILES, R.; FUENTES, P.I.:

The effect of low doses of naloxone on the preovulatory surge of LH and on the onset and duration of estrus in the ewe with induced oestrus during the non-breeding season. Anim. Reprod. Sci. 65 (2001), 225-230

GALLEGOS-SANCHEZ, J.; MALPAUX, P.; THIERY, J.C.:

Control of pulsatile LH secretion during seasonal anoestrus in the ewe. Reprod. Nutr. Dev. 38 (1998), 315

GHOSH, B.R.; WU, J.C.; MILLER, C.L.:

Gonadotropin-releasing hormone-stimulated calcium mobilization is altered in pituitary cultures from anestrous ewes. Biol. Reprod. 54 (1996), 753-760

GOODMAN, R.L.; PARFITT, D.B.; EVANS, N.P.; DAHL, G.E.; KARSCH, F.J.:

Endogenous opioid peptides control the amplitude and shape of gonadotropin-releasing hormone pulses in the ewe. Endocrinology 136 (1995), 2412-2420

GIUCCI, E.; KAULFUSS, K.H.:

A comparing study using ultrasonography to determine the seasonality of the reproduction in sheep. 35 . Jahrestagung Physiologie und Pathologie der Fortpflanzung, 14.02.-15.02.2002, Leipzig, P2.10

HARESIGN, W.: Manipulation of reproduction in sheep. J. Reprod. Fertil. Suppl. 45 (1992), 127-139

KANITZ, E.; KANITZ, W.; DELZER, W.; SCHMIDT, H.E.; KITZIG, M.; SCHNEIDER, F.: Die Nutzung der LH-Analytik zur Bestimmung des optimalen Besamungszeitraumes nach Superovulationsbehandlungen. Mh. Vet. Med. 45 (1990), 123-125

KARSCH, F.J.; BOWEN, J.M.; CARATY, A.; EVANS, N.P.; MOENTER, S.M.: Gonadotropin-releasing hormone requirements for ovulation. Biol. Reprod. 56 (1997), 303-309

KAULFUSS, K.H.; SUESS, R.; RUMMER, K.; PRANGE, H.; BORELL, E. von: Ovarian reaction after pheromone application in anoestrous German Mutton Merino ewes in relation to ovary state before stimulation. EAAP $-48^{\text {th }}$ Annual Meeting, Vienna 1997, Book of Abstracts No. 3, p. 289, S 3.6

KAWATE, N.; OKUDA, K.:

Coordinated expression of splice variants for luteinizing hormone receptor messenger RNA during the development of bovine corpora lutea. Molec. Reprod. Develop. 51 (1998), 66-75

KHALID, M.; BASIOUNI, G.F.; HARESIGN, W.:

Effect of progesterone pre-treatment on steroid secretion rates and follicular fluid insulin-like growth factor-1 concentrations in seasonally anoestrous ewes treated with gonadotrophin releasing hormone. Anim. Reprod. Sci. 46 (1997), 69-78

KNIGHTS, M.; MAZE, T.D.; BRIDGES, P.J.; LEWIS, P.E.; INSKEEP, E.K.: Short-term treatment with a controlled internal drug releasing (CIDR) device and FSH to induce fertile estrus and increase prolificacy in anestrous ewes. Theriogenology 55 (2001), 1181-1191

LINCOLN, G.A.: Photoperiod-pineal-hypothalamic relay in sheep. Anim. Reprod. Sci. 28 (1992), 203-217

MALPAUX, B.; THIERY, J.C.; CHEMINEAU, P.: Melatonin and the seasonal control of reproduction. Reprod. Nutr. Dev. 39 (1999), 355-366

MOENTER, S.M.; CARATY, A.; KARSCH, F.J.:

The estradiol-induced surge of gonadotropin-releasing hormone in the ewe. Endocrinology 127 (1990), $1375-1384$

O'CALLAGHAN, D.:

A practical approach to the management of reproductive seasonality in sheep. Reprod. Dom. Anim. 34 (1999), 285-291

PETERS, K.J.:

Zuechterische Aspekte der Lammfleischproduktion. Arch. Tierz., Dummerstorf 43 (2000) Sonderheft, 98-105

REHBOCK, F.; SCHNEIDER, F.; ZUPP, W.; GRUMBACH, S.:

Seasonal influences on blood plasma progesterone concentration in ewes of Blackhead Mutton sheep breed (short communication). Arch. Tierz., Dummerstorf 42 (1999), 183-189 
REKWOT, P.I.; OGWU, D.; OYEDIPE, E.O.; SEKONI, V.O.:

The role of pheromones and biostimulation in animal reproduction. Anim. Reprod. Sci. 65 (2001), $157-$ 170

RICHTER, T.A.; ROBINSON, J.E.; EVANS, N.P.:

Progesterone blocks the estradiol-stimulated luteinizing hormone surge by disrupting activation in response to a stimulatory estradiol signal in the ewe. Biol. Reprod. 67 (2002), 119-125

ROSA, H.J.D.; JUNIPER, D.T.; BRYANT, M.J.:

Effects of recent sexual experience and melatonin treatment of rams on plasma testosterone concentration, sexual behaviour and ability to induce ovulation in seasonally anoestrous ewes. J. Reprod. Fertil. 120 (2000), 169-176

SCHNEIDER, F.; BELLMANN, A.; BECKER, F.; BAMBANG PUERNOMO, S.; REHFELDT, C.; NUERNBERG, G.; KANITZ, W.:

Gonadotropin release in periovulatory heifers after GnRH analogs measured by two types of immunoassays. Exp. Clin. Endocrinol. Diabetes 110 (2002), 1-10

SOUZA, C.J.H.; CAMPBELL, B.K.; BAIRD, D.T.:

Follicular dynamics and ovarian steroid secretion in sheep during anoestrus. J. Reprod. Fertil. 108 (1996), 101-106

STENBAK, T.K.; REDMER, D.A.; BERGINSKI, H.R.; ERICKSON, H.S.; NAWANUKRAW, C.; TOUTGES, M.J.; BILSKI, J.J.; KIRSCH, J.D.; KRAFT, K.C.; REYNOLDS, L.P.; GRAZUL-BILSKA, A.T.:

Effects of follicle stimulating hormone (FSH) on follicular development, oocyte retrieval, and in vitro fertilization (IVF) in ewes during breeding season and seasonal anestrus. Theriogenology 56 (2001), 5164

UNGERFELD, R.; RUBIANES, E.:

Effectiveness of short-term progestogen primings for the induction of fertile oestrus with eCG in ewes during late seasonal anoestrus. Anim. Sci. 68 (1999), 349-353

ZUNIGA, O.; FORCADA, F.; ABECIA, J.A.:

The effect of melatonin implants on the response to the male effect and on the subsequent cyclicity of ZUPP, W.: Rasa Aragonesa ewes implanted in April. Theriogenology 72 (2002), 165-174

In: Agrarprofi - Landesforschungsanstalt fuer Landwirtschaft und Fischerei M-V, AgriMedia Verlag, 2002, 05.06.03-04

ZUPP, W.; REHBOCK, F.:

Wie saisonal sind Fleischschafe? Bauernzeitung (2000) 18, 66-67

Received: 2002-10-16

Accepted: 2002-12-06

Authors' addresses

Dr. FALK SCHNEIDER

Unit of Reproductive Biology

Research Institute for the Biology of Farm Animals

Wilhelm-Stahl-Allee 2

D-18196 Dummerstorf

Germany

E-Mail: falk.schneider@fbn-dummerstorf.de

\section{Dr. FRANK REHBOCK}

State Research Institute of Agriculture and Fishery Mecklenburg-Vorpommern, Institute for Animal Production

Wilhelm-Stahl-Allee 2

D-18196 Dummerstorf

Germany

E-Mail: rehbock@lfa-mv.de 